\title{
Intellectual Corruption at the APA
}

\author{
James F. Welles* \\ East Marion, New York, USA
}

*Corresponding author: James F Welles, East Marion, New York, USA

\section{Introduction}

A book I wrote, Understanding Stupidity, was reviewed by Dr. Thomas O. Blank of the School of Family Studies and Center on Aging at the U. of Connecticut, Storrs. The review appeared in the Sept. 1993 issue of Contemporary Psychology, a journal of reviews published by the American Psychological Association (APA). It was very harsh, in some ways un professional and demonstrated Dr. Blank's inability to understand what he had read. I availed myself of the opportunity to respond in the "Point/ Counterpoint" format made available to aggrieved authors by the journal. This consisted of a four-part exchange of statements between myself and Dr. Blank and appeared in the May 1994 issue. In his last comment, to which I had no opportunity to reply in print, he alleged that my stated view "Normal human behavior is not necessarily adaptive" could be accessed (i.e., found) elsewhere.

I received an advanced copy of this statement and twice challenged him in writing to document his claim but received not even the courtesy of a reply. In April, I wrote Dr. John Harvey, the editor of the journal, asking him to see to it that Dr. Blank document his claim or that an appropriate correction be published in a forth coming issue. He was explicit in his refusal to do anything to resolve the matter. I then turned to the APA and had a number of phone con variations and exchanged letters with Leslie Cameron, Director, APA Journals, in May and June regarding this matter, all to no effect. Dr. Gary VandenBos, Executive Director, Publications and Communications, called me in early June and we spoke for about an hour. He assured me Dr. Blank was correct in saying my idea could be found elsewhere, but when challenged to document the claim, like everyone else, he failed to do so. In late June, I wrote, Dr. Raymond Fowler, Chief Executive Officer, again to no effect.

He claimed the APA was out of op tions at this point, because they could not force Dr. Blank to document his claim. I pointed out they could request him to do so or publish a correction on their own but received no reply to these suggestions. (A year later, in an attempt to document the claim, Deputy CEO L. Michael Honaker misinterpreted a statement never made in a text to mean the exact opposite of what the author cited believed.) In Aug. 1994, I commenced a likewise fruitless effort to get the University of Connecticut to hold Dr. Blank accountable. After a brief phone conversation with me, Dr. Steven Anderson, Dean of the School of Family Studies, prevailed upon him to send me a list of books (with no page numbers) in which he did not even try to document the claim he had made in print. He tried instead to document a substitute claim-that maladaptation was a central theme in the books listed. Mal adaptation is in fact a common behavioral phenomenon, but that was not the issue in dispute, so I asked him once again to document his claim that my idea that normal behavior can be non or maladaptive could be accessed somewhere other than my book but received no reply.

Dr. Fred Marianski, Associate Provost for Academic Affairs, deftly avoided involvement by claiming the issue was not in his field of expertise so he would "Leave it to the professionals". His superior, Dr. Thomas Tye, Vice President and Provost for Academic Affairs, failed to return several phone calls. Presi dent Dr. Harry Hartley was properly insulated by staffer Carol Flynn, who thwarted my efforts to inform him of his dysfunc tional faculty and administrators on the grounds that he has no control over academic affairs presumably in the same way the President of General Motors has nothing to do with making cars. At the conclusion of my one phone conversation with Dr. Richard Besdine, Director of The Traveler's Center on Aging, he assured me either he or Dr. Blank would get back to me: I heard from neither. Likewise, the American Association for the Advancement of Science failed to hold either Dr. Blank or anyone else ac countable in this matter. Rather than dealing with it as an error in the scientific literature, Dr. C. K. Gunsalus's Committee on Scientific Freedom and Responsibility feigned psychosis and claimed they simply did not perceive the issue as I did. 
One way to advance science is by cor recting errors in the literature: they just did not perceive an undocumentable claim as an error (and besides, redefining Darwinian psychology is too petty a matter to bother with). Thus did the scientific establishment react to an error in the literature. Striking by its absence in all parties was any trace of intellectual integrity. Not one insisted Dr. Blank document his erroneous claim that my idea could be found elsewhere or publish a correction. He had made an error, so everyone circled the wagons to protect him. I have never known a case where so many welleducated people have distinguished right from wrong and deliberately, knowingly and wittingly chosen to be wrong. How nice it would be to add that Dr. Blank's allegation that the idea that normal is not necessarily adaptive has been documented or his error corrected. Sad to say, neither case obtained. Rather, my experience has confirmed the central idea of the book-that our social and political lives warp our intellectual life, and there is no better example of this phenomenon than the intransigence with which the academic/scientific establishment stands by its error in this particular case.

This is all the more remarkable because the institutions involved have rules which call for all parties to conduct themselves properly, but a basic problem is that they prefer to break rather than abide by or enforce their own rules for proper professional conduct. Cognitive dissonance, anyone? The University of Connecticut has bylaws which require accuracy on the part of all faculty members at all times, but the fact that Dr. Blank has published misinformation is of no moment to anyone at that institution. Further, all members of the university community are required to foster intellectual honesty, but no one involved with this case has done anything that could possibly be construed as so doing. For example, in January, 1997, when I asked the new president, Philip Austin, to secure a proper reference for me from Dr. Blank, he replied he had no advice for me. In turn, I pointed out I had not asked him for advice and repeated my request that he get a faculty member to document a published claim.

He never responded. So also, were the dean of the Graduate School, Thomas Gi olas, and Provost Mark Emmert absolutely adamant in their refusal to abide by much less enforce their own bylaws. The basic dodge was that since the APA has done nothing to remedy the situation, nothing is wrong. Aside from the obvious fact that this is passing the buck and a total abnegation of academic responsibility on the part of the school's chief administrators, this tactic is based on a major fallacy: it assumes the APA is a professional scientific organization dedicated to truth. Unfortunately, it is not. At the very best, the APA is a public relations outfit dedicated to promoting the power, status, image, careers and incomes of its members. Just in the course of trying to get the matter at hand corrected, I stumbled across a number of un corrected errors published in APA journals dating back to 1970. In Robyn Dawes' published letter of resignation from the organization in 1988, he cited the lack of commitment on its part to the rational application of knowledge as a requirement and stated his view that the organization had failed miserably to assure a professional practice of psychology based on available scientific knowledge.

Such a flagrantindifference to factual knowledge is unfortunately common at the APA (which, in my lighter moments, I refer to as the American Psychotics Association because of the administrators' casual disregard of reality). For example, Dr. Dawes referred to the organization's efforts to convince the public its members have a special expertise not only in the ab sense of any evidence for such expertise but indeed in the face of evidence that it does not exist. So, in my case, the fact that no one could document Dr. Blank's allegation meant nothing to anyone at the APA. Typical of the mishandling of this case was the action of Dr. Norman Abeles when he chaired the APA publications and communications (P\&C) board. In June 1995, the board determined no further action (i.e., documentation) was required in the matter, but it based this decision on the mistaken belief that Dr. Blank had provided a reference.

When I pointed this error out to him and asked him to reconsider and base the decision on the facts, he refused to do so and thence became president of the organization. In February and March 1997, I repeatedly asked the new chair of the P\&C board, Prof. Judith Worrell, to place this matter on its agenda but all to no effect: she just would not deal with the issue. As for the AAAS, the story is essentially the same: the con situation requires the promotion of responsibility, but no one will deign to do anything in this case to hold those involved accountable to basic standards of science. President Jane Lu bchenco passed up an opportunity in August 1996, by side stepping the issue. In this regard, she was but typical of all par ties contacted: none would deal with the problem, so by default, every decision by everyone favored misinformation. The basic problem really is that no one cares about the publication of an error in the scientific literature.

Dr. Blank published a fallacious statement, but so what? Those who are supposed to be exercising control over the quality of science are frankly indifferent to such breaches of intellectual ethics. (In deed, in February 1997, the APA's Office of Ethics, Dr. Stanley Jones presiding, declined to investigate this case-leading one to conclude that the publication of an undocumentable statement is ethical.) The bottom line is that science is not a self-correcting in situation. Perhaps sometimes it is but not always and no necessarily. If I had to present one good example of institutional stupidity to the world, this would be as good as any. All these professors and Ph.D.'s with all their education evince not the slightest interest in much less even a minimal commitment to knowledge or truth. Not one! Not one stood up for the truth and said, "There is something wrong here, let's fix it." From this I conclude there is something very wrong with our educational system, and I hope someone will fix it.

Our best educated elite have absolutely no ethical qualms whatsoever in their professional field of expertise. The saddest commentary I can make on the possibility science will save us is 
that it will be inhibited to the degree scientists refuse to deal with the reality of unethical conduct. Sad to say, in Jan. 2019, there is nothing encouraging to add to the above. An update of this Update would simply be that the APA stands by its error. Its preferred tactic to rationalize this intellectual disgrace has been to substitute its own version of a complaint for mine. Hence, those who consult the file in the APA's office do not even know what my complaint is. They conclude there is no problem because the APA prevents them from finding out what the problem is. The fact is a published error remains uncorrected, and although rationalizations abound, there is no justification for that whatsoever. My final take on this whole sad incident is that it can be in credibly difficult (if not impossible) to get people to do what is right.

In a larger historical context, the conduct of those at the APA's fits eerily well with St. Augustine's observation: "How cunningly and with what exquisite wit have the philosophers and heretics defended their very errors-it is strange to imagine!" (ca. 420.The City of God) Sixteen hundred years later, civilization has advanced to the point that we can add scientists and academicians to the group, which might lead a cynic to conclude that what we deem as progress in education is un questionably accompanied if not characterized by an expansion of intellectual corruption to new fields. For fuller account of this unfortunate affair, see Welles, J. Spring, 2004. In Defense of an Error: Intellectual Corruption in Contemporary Science. Journal of Information Ethics, Vol 13, \#1, 38 50 .

\section{Chapter 11 (Factually Bankrupt) Boring Man Bites Boring Dog}

James F. Welles wrote two books on stupidity, and perhaps he may want to include a new chapter on himself. Old Jim, author, has been charged after allegedly biting a police dog during a fight outside a bar and has been charged with injuring a police animal, resisting arrest and obstruction. This terrible event happened after a police officer and his German shepherd, named Renny, went to investigate a disturbance outside a bar in Syracuse, New York state. Police say Welles and a friend had got into a fight with bouncers after being asked to leave the premises. However, and this is where the story really starts, according to police reports, Jim Welles grabbed the dog, Renny, by the throat and started choking the animal and biting it on the left side of his neck. "I don't think I bit the dog. I just got into a fight with him. I don't really remember. I was pretty drunk," Welles allegedly told police. After treatment at a local hospital, Jim was detained overnight before appearing in court, and later released on bail. Renny apparently was a little sore but is not thought to have suffered any lasting damage.

A Susanna Duffy, whoever she is-maybe a stooge for the APAput this on the internet and asked for a new chapter, so here. It just shows to go you what you can find on the net. Needless to say, this story is not about me as I was in Florida at the time. What is worse, the courageous Ms. Duffy put this blog out knowing it was not about me. The original story ran with a Paul Russel, 33, as the named suspect, and my name was simply substituted for Mr. Russel's. For some reason, Ms. Duffy had it in for me and used the internet as a way of impugning my otherwise pecable character. (And, at 77, I resent being referred to as "Old".) JFW
This work is licensed under Creative Commons Attribution 4.0 License

To Submit Your Article Click Here: Submit Article

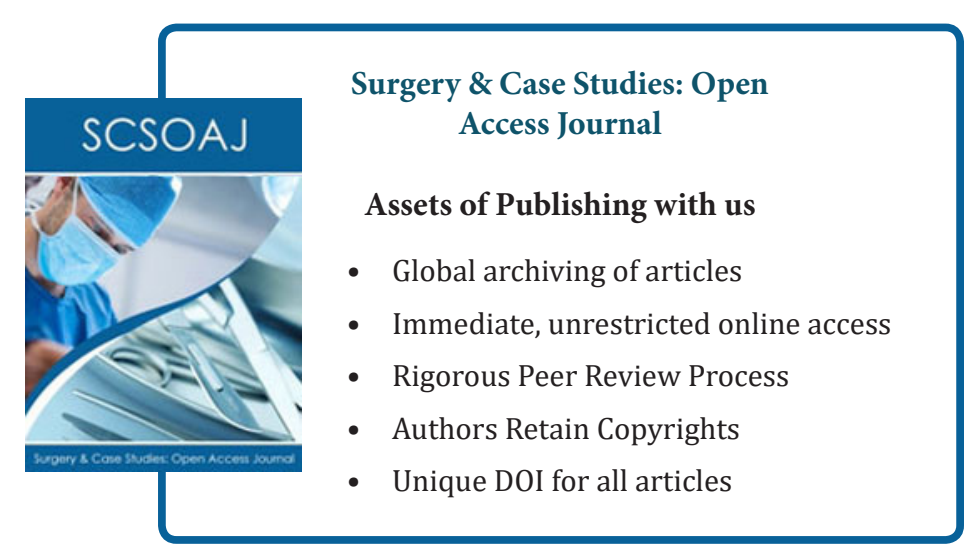

